\title{
Evaluation of Program Implementation in Industrial Work Practices of State Vocational High School 3 of Students in Batam
}

\author{
Nurjanah $^{1}$, Fahmi Rizal $^{2}$, Asmar Yulastri $^{3}$, Yaslinda Lizar ${ }^{4}$, B.Herawan Hayadi ${ }^{5}$ \\ Master of Technology and Vocational Education Masters Program, Faculty of Engineering, \\ Padang State University, Padang, Indonesia ${ }^{1,2,3}$ \\ UIN Imam Bonjol Padang Indonesia ${ }^{4}$ \\ University of Pasir Pengaraian, Riau Indonesia ${ }^{5}$ \\ \{nurjanahmukhtar1983@gmail.com $\left.{ }^{1}\right\}$
}

\begin{abstract}
State 3 in Vocational High School 3 in Batam has a Vision: to create a character, quality and professional students to produce graduates with entrepreneurial and competitive spirits in the era of globalization. The missions are: 1) Applying the value of national character in every activity in the School, conducting teaching and learning through competency-based training, 2) Implementing student-centered learning, 3) Improving collaboration with parties Business and Industrial World field to improve teacher and student competencies as well as graduates' absorption, 4) Establishing entrepreneurial spirit through production and service units, 5) Instilling quality and professional work culture for school progress, 6) Creating and maintain environment clean, healthy, beautiful, safe and comfortable school, 7) Completing the supporting facilities of the teaching and learning process so that the creation of a quality learning process that links and matches according to the needs of the business and the industry. Based on the Vision and Mission of State Vocational High School 3 in Batam, where State Vocational School 3 in Batam is one of the middle-level education units that process students to compete in the workforce, market demands and changes that occur due to the development of science and technology can be fulfilled. Therefore, State Vocational High School 3 in Batam implements the Industrial Internship Program. The results of data analysis indicate that the implementation of the Industrial Internship Program of state Vocational High School 3 in Batam in general has gone well, but there are still some parts that need to be improved. This can be seen from the data obtained by the researcher. The data is certainly related to the program evaluation section. Provides an explanation of the UCLA-CSE model into four stages, namely: 1) Assessment Needs, focusing on determining the issues that need to be considered in the program, program requirements and program objectives, 2) Program Planning, planning the evaluation program is to find out whether the program is compiled according to the needs analysis or not by involving elements of program implementation, 3) Formative Evaluation, evaluation is done to find out the program's implementation, 4) Summative Program, evaluation is to find out the results and impacts of the program and to find out the program's achievements.
\end{abstract}


Keywords: Batam, Visions, Missions

\section{Introduction}

Vocational High Schools have several programs to train and educate students to have competencies that can be applied to future life. The program is a combination of several components and sub-components in it. Whether a program depends or not on the contents of the components and sub-components that are in it. The program is a system; a system is a unit of several parts or components of programs that are interrelated and work together to achieve the goals set in the system according to Arikunto [1]-[4].

The program was made to answer the challenges of the industry, namely the implementation of the Industrial Internship program[5]-[7]. This program is a form of implementation of the 2013 curriculum that is implemented in Vocational High Schools. According to the DPSMK on the Ministry of Education and Culture (2017) the objectives of the Industrial Internship Program are: 1) Providing direct (real) work experience to students in order to internalize a positive work climate oriented to quality, process and work outcomes, 2) Instilling a high work ethic for students to enter the world of work in the face of the demands of the global labor market, 3) Fulfilling the competencies that have not been given by schools to achieve the needs of graduate competency standards, 4) Actualizing one form of activity in the implementation of the Dual System Education model between Vocational High Schools and Pair Institutions of Business and Industry. In the Industrial Internship Program, there are many components and sub-components that support this program to run well. These components include: 1) Industrial Internship Program Objectives, 2) Industrial Internship Program Environment, 3) Students, 4) Advisory Teachers, 5) Curriculum, 6) School Workshop Tools 7) Preparation for Industrial Internship Program Implementation, 8) Implementation Procedure of Industrial Internship Program, 9) Relevance of Industrial Internship Program, 11) Obstacles to Industrial Internship Program 12) Results of Industrial Internship Program and 13) Impact of Industrial Internship Program . One of the Vocational High Schools that implemented the Industrial Internship Program was the state Vocational High School 3 in Batam. This Vocational High School was established in 2007 on Jl. Letjend S. Parman, Kelurahan. Duriangkang, District of Sei Beduk, Batam city of Kepulauan Riau. Vocational High School 3 in Batam has 6 competency skills, namely: Cooling and Air Conditioning Engineering, Industrial Electronics Engineering, Computer Network Engineering, Light Vehicle Engineering, Motorcycle Engineering, and Clothing. (Source of Public Relations of Vocational High School 3 in Batam: 2018)[8]-[10].

State Vocational High School 3 in Batam has some Visions: Creating character, quality and professional students to produce graduates who are entrepreneurial and competitive in the era of globalization. The missions are: 1) Applying the value of national character in every activity in the School, conducting teaching and learning through competency-based training, 2) Implementing student-centered learning, 3) Improving collaboration with the Business and Industry to improve teacher and student competencies as well as graduates' absorption, 4) Establishing entrepreneurial spirit through production and service units, 5) Instilling quality and professional work for school progress, 6) Creating and maintain a school environment clean, healthy, beautiful, safe and comfortable, 7) Completing facilities to support the teaching and learning process so that the creation of quality learning processes that link and match according to the needs of the business and the industry.. Based on the vision and mission of the State Vocational High School 3 in Batam, where the State Vocational High School 3 in Batam is one of the middle-level education units that process students to compete in the work, 
market demands and changes that occur due to the development of science and technology can be fulfilled. Therefore, the State Vocational High School 3 in Batam implemented the Industrial Internship Program[11].

\section{Method}

The type of research used is quantitative and qualitative research using an evaluative descriptive approach. Evaluative research is to find out the final results of a policy program to determine recommendations for further policy, according to Arikunto[12].

This quantitative research is carried out using statistical and qualitative processing numbers in this study as reinforcement of quantitative findings conducted through interviews with research subjects. In this study, researchers used a CSE-UCLA program evaluation model (Center for Study of Evaluation-University of California Los Angeles).

\section{Result and discussion}

The results of data analysis from the results of questionnaires given to 57 students consisted of 5 items, with the possibility of a minimum score of 5 and a maximum score of 25 , obtained by the respondent's achievement level of 79\% in the "Enough" category, while the frequency distribution of respondents' achievement in Industrial Internship Program students can be seen in Table 1.

Table 1. Impacts of the Industrial Internship Program

\begin{tabular}{|l|c|c|}
\hline \multicolumn{1}{|c|}{$\begin{array}{c}\text { Category of Respondent Achievement } \\
\text { Levels ( TPR ) }\end{array}$} & Frequency & Percentage \\
\hline Very good & 17 & $30 \%$ \\
\hline Good & 13 & $23 \%$ \\
\hline Enough & 20 & $35 \%$ \\
\hline Less & 4 & $7 \%$ \\
\hline Very less & 3 & $5 \%$ \\
\hline & 57 & $100 \%$ \\
\hline
\end{tabular}

The results in Table 1 can be presented in visual form in the following figure: 


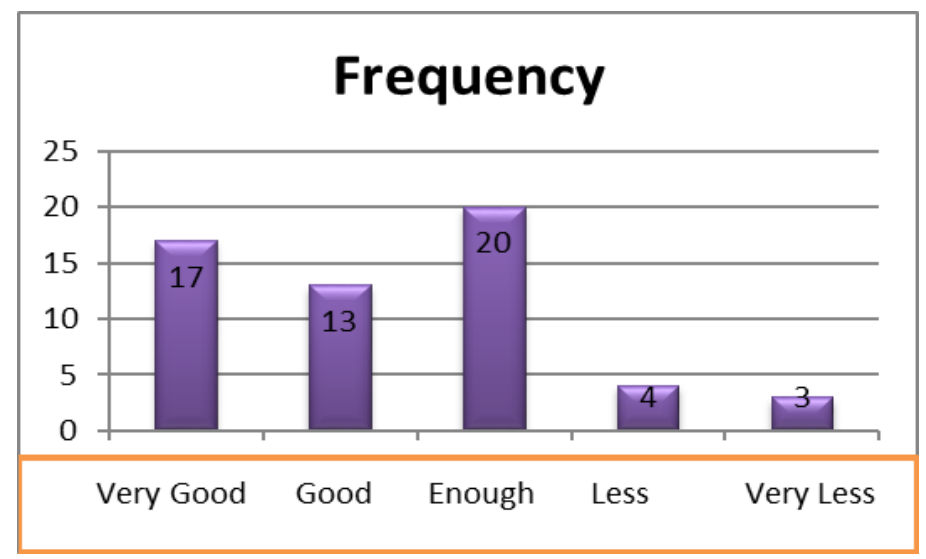

Figure 1. Impacts of the Industrial Internship Program

Based on the data in table 1, the results of respondents' achievement on the impact indicators of Industrial Internship Program, at a very good level of 7 or $30 \%$, either 13 or $23 \%$, enough 20 or $35 \%$, while less 4 or $7 \%$ and less 3 or $5 \%$. The results of interviews with four students who have implemented the Industrial Internship Program and are spread in 4 Businesses and Industry generally state that:

"When we finished implementing the Industrial Internship Program, we were able to feel the positive impact: having a good communication relationship with the school and the business and industrial party, it was easier to get work opportunities, ready to plunge into the business world and the industry and have a high working spirit.

The results of data analysis show that the implementation of the Industrial Internship Program at the state Vocational High School 3 in Batam, in general, has gone well, but there are still some parts that need to be improved. This can be seen from the data obtained by the researcher. The data is certainly related to the program evaluation section.

According to Fernandes (Arikunto: 2004), he provides an explanation of the UCLA-CSE model into four stages, namely: 1) Assessment Needs, is to focus on determining the issues that need to be considered in the program, program requirements and program objectives, 2) Program Planning, the evaluation program is to find out whether the program is compiled according to the needs analysis or not by involving elements of program implementation, 3) Formative Evaluation, evaluation is done to find out the program's implementation, 4) Summative Program, evaluation is to find out the results and impacts of the program and to find out the program's achievements.

\section{Conclusion and suggestions}

Based on the results of the Implementation Evaluation study on the Industrial Internship Program of the students of state vocational high school 3 in Batam in the expertise competencies in the Computer Network Engineering department and the Cooling \& Air Conditioning Engineering that has been done, the following conclusions are obtained:

\section{Component of Needs Assessment}

Based on the results of the respondents' achievement in the Assessment Needs component of each indicator so that the total score of the presentation can be obtained from the 
aspects of the Industrial Internship Program objectives and the environment in which the Industrial Internship Program is in a good category.

\section{Component of Program Planning}

Based on the results of the respondents' achievement in the Program Planning component of each indicator so that the total score of presentations can be obtained from 7 aspects of student readiness, guidance teacher, curriculum, workshop equipment, preparation of Industrial Internship Program implementation, procedures for implementing of Industrial Internship Program and the Industrial Internship Program committee in good categories.

\section{Component of Formative Evaluation}

Based on the results of the level of achievement of respondents in the Components of Formative Evaluation of each indicator so that the total score of the presentation can be obtained from both aspects of program relevance and obstacles to Industrial Internship Program is in good categories.

\section{Component of Summative Evaluation}

Based on the results of the respondent's level of achievement in the Component of Summative Evaluation of each indicator so that the total score of the presentation from the two aspects of the results of Industrial Internship Program can be obtained and the impact of Industrial Internship Program is in a good category.

From the conclusions above, there are some suggestions that the authors convey to help improve the Industrial Internship program as follows:

1. The Industrial Internship Program helps to improve student competency; it is recommended to proceed with correcting the weak points of evaluation research findings including:

a. skills competency is still lacking

b. Student ethics and discipline are still lacking

2. In implementing New Student Admission, it is recommended to cooperate with business and industry to determine requirements and selection specifically related to student performance criteria by their respective majors.

3. The selection of Industrial Internship program of supervisors is advised to be carefully selected so that the teacher is chosen to be able to guide students in the field and be responsible.

4. The process of improving the Teaching and Learning Process in schools is suggested to reflect on the results of evaluating the implementation of Industrial Internship student programs in the industry.

Schools are advised to improve the Cooling and Air Conditioning Engineering workshop so that the learning of Productive subjects can be carried out to the maximum

\section{References}

[1] G. Chen, "Innovation and Practice of Training High-Skilled Workers by SchoolEnterprise Cooperation in Higher Vocational Education," in 2011 Fourth International Symposium on Knowledge Acquisition and Modeling, 2011, pp. 549-551.

[2] J. Chang and Y.-L. Tu, "Students' perspective on teachers' innovative teaching in vocational high schools," in 2012 International Conference on Innovation Management and Technology Research, 2012, pp. 183-187.

[3] C. Lin and J.-H. Pan, "Experimental Setups of Scorm Based E-Learning Environments for a Computer-Aided Drafting Course at a Vocational High School," in 2006 International Conference on Information Technology: Research and Education, 2006, 
pp. 206-210.

[4] C. Chiu, "Programming Examples Analysis of Commercial Vocational High School Textbooks in Taiwan," in 2015 International Conference on Learning and Teaching in Computing and Engineering, 2015, pp. 223-224.

[5] G. W. Schmid-Schonbein, "The industrial internship program at UCSD bioengineering," in Proceedings of the First Joint BMES/EMBS Conference. 1999 IEEE Engineering in Medicine and Biology 21st Annual Conference and the 1999 Annual Fall Meeting of the Biomedical Engineering Society (Cat. No.99CH37015), 1998, vol. 2, p. 1258.

[6] P. Sanchis et al., "New organizational and assessment frameworks for company internship programs," in 2017 IEEE Global Engineering Education Conference (EDUCON), 2017, no. April, pp. 877-882.

[7] N. I. Ismail, M. A. Md Yusof, and A. P. Herman, "Work Based Learning Strategy through a Strutured Industrial Internship Program for Undergraduate," in 2017 th World Engineering Education Forum (WEEF), 2017, pp. 882-887.

[8] X. Miao, G. Peng, X. Ma, J. Li, and W. Liu, "Energy Saving and Economical Analysis of Frequency Conversion Operation for Cooling Water Pumps in Underground Engineering Air Conditioning System," in 2009 Asia-Pacific Power and Energy Engineering Conference, 2009, vol. 3, no. 4, pp. 1-4.

[9] C. Wang, X. Huang, and Z.-X. Wu, "Researches on the Evaporative Cooling Air Conditioning Standard of Utilizing Renewable Energy Dry Air Cooling," in 2010 4th International Conference on Bioinformatics and Biomedical Engineering, 2010, pp. $1-4$.

[10] D. Puyada, G. Ganefri, A. Ambiyar, R. E. Wulansari, and B. Herawan Hayadi, "Effectiveness of interactive instructional media on Electrical Circuits," Int. J. Eng. Technol., vol. 7, no. 2.14 Special Issue 14, 2018.

[11] Y. R. Matsuoka, G. A. R. Sandoval, L. P. Q. Say, J. S. Y. Teng, and D. D. Acula, "Enhanced Intelligent Character Recognition (ICR) Approach Using Diagonal Feature Extraction and Euler Number as Classifier with Modified One-Pixel Width Character Segmentation Algorithm," in 2018 International Conference on Platform Technology and Service (PlatCon), 2018, pp. 1-6.

[12] S. Arikunto, Prosedur penelitian: Suatu pendekatan praktik. Jakarta: Bumi Aksara, 1992. 